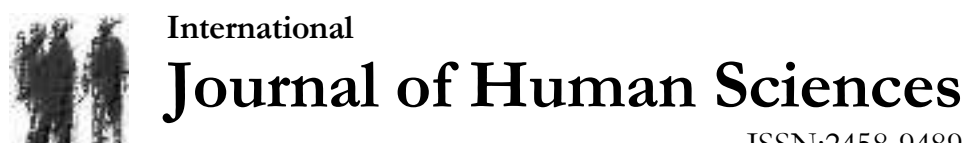 \\ ISSN:2458-9489
}

Volume 17 Issue 4 Year: 2020

\section{Consumers' knowledge level, attitudes, behaviours and acceptance of GM foods}

\author{
Nevin Şanlıer ${ }^{1}$ \\ Aybuke Ceyhun Sezgin ${ }^{2}$
}

\begin{abstract}
Research aim: The aim of the study was to investigate the consumers' opinions about genetically modified (GM) foods in Turkey. A framework was conceptualized and conducted in educated consumers. Method: A questionnaire about consumers' knowledge, attitudes, behaviors, and perceptions was performed to 1307 individuals. Data were collected through faceto-face conversations with the questionnaire. The convenience sampling method was used for data collection and a voluntary basis was taken into account while selecting the participants. All statistical analyses were performed using SPSS 16.0. According to the results the genetically modified foods knowledge scores $(4.53 \pm 0.74)$ of married individuals are high $(\mathrm{p}<0.001)$, single individuals' GM foods attitude, behavior and perception scores have also been found to be statistically significantly high $(26.55 \pm 5.95)(p<0.001)$. Findings: Furthermore, there exist a positive correlation between the attitude, behavior and perception scores. Age, gender and marital status of highly educated consumers' influence their knowledge and attitudes about GM foods, but the attitude, behavior and perception scores show that individuals are concerned about GM foods. Conclusions: It is seen that consumers do not have sufficient knowledge about genetically modified foods but that they want to be informed. According to the results of this study, consumers focus more on the harmful aspects of the benefit/harm relationship of GM foods. In this study, it was determined that women were suspicious of genetically modified foods compared to men. This study reflects about consumers opinions and provides information about the studies and enforcements will be executed in this regard in the future.
\end{abstract}

Keywords: Biotechnology; Consumer; Genetically Modified Food.

\section{Introduction}

Genetically modified (GM) products have been involved among contradictory and concerning subjects since introduced to food supply in 1990s (Moodie, 2016). Genetically modified organisms (GMOs) are a result of research studies in modern biotechnology on food production in many sectors, primarily in agriculture and health. The incredibly fast-progressing gene technology is now not only a research field, but also has become part of many areas of daily life, such as health, foods, and animal feeds (Baylan, Mazı, \& Gündoğdu, 2015; Azadi et al., 2015).

\footnotetext{
1 Prof. Dr., Ankara Medipol University, School of Health Sciences, Department of Nutrition and Dietetics, nevintekgul@gmail.com (D) Orcid ID: 0000-0001-5937-0485

2 Assoc. Prof. Dr., Ankara Hac1 Bayram Veli University, Faculty of Tourism, Department of Gastronomy and Culinary, aybuke.ceyhun@hbv.edu.tr (D) Orcid ID: 0000-0003-1068-9940
} 
Şanlıer, N., \& Ceyhun Sezgin, A. (2020). Consumers' knowledge level, attitudes, behaviours and acceptance of GM foods. Journal of Human Sciences, 17(4), 1235-1249. doi:10.14687/jhs.v17i4.6016

Almost all of the GMO products produced for the nutrition of humans and animals are of plant origin. Today, the use of genetically modified animals in animal production is much lower than that of plant-based products (Cebirbay \& Aktas, 2018). Corn/maize, soybean, cotton, cole, potato, tobacco, and rice are among the most-produced genetically modified (GM) foods (Ozdemir \& Duran, 2010; Domingo, 2016).

Those who support genetically modified organisms claim that this technology has many benefits such as increase food quality and health benefits, prolongation of shelf life of fruits and vegetables, improvement in sensorial characteristics, increase of product yield, production of edible vaccination and drugs, treatment of human diseases and environmental benefits (Vines, 2002; Vujaklija, 2006). Those criticizing these organisms claim that the change in food quality, food safety, allergic and toxic effects may appear in case of violation of consumer rights as well as religious, cultural and ethical problems by concerns of environmental and different groups (Çelik \& Balik, 2007; Paoletti et al., 2008); although it is considered as a potential solution for food crisis in the world, it is deemed as a potential hazard for human health, environment and bio-diversity (Gurau \& Ranchhod, 2016). In addition, genetic modification of food has been shown to cause serious problems in the food sector. However, although the supporters of genetic modification of foods due to several advantages, such as obtaining products with desired features at low-cost, several researchers and the general public have serious concerns about the subject (FAO, 2012). Although the uncertainties, risks, and benefits about this new technology have been commonly argued, the prevalence of its use in the food industry has increased (Uzunkol, 2012). The United States, Argentina, Brazil, India, Canada, and China are the biggest producers and exporters of GM foods (FAO, 2012). The International Service for the Acquisition of Agri-biotech Applications (ISAAA) report that total planting area of GM products increased by 100 -folds while it was 1.7 million hectares in 1996. Accordingly, GM product plantation was detected on an area of 189.8 million hectares in 24 countries in 2017 (ISAAA, 2017). Genetically modified (GM) products have been an important product of food industry. Totally, 357 GM products were approved between 1996 and 2014; and they consisted 35\% of world seed market. Rapid growth of GM product based industry caused discussions in many regions including European Union, Egypt, Japan, Korea, Brazil and Taiwan (Lin \& Pan, 2016). Genetically modified foods have been common in the markets and American diets. The Grocery Manufacturers Association reports that majority of packed foods in USA includes GM organisms (Moodie, 2016).

The labelling of GM foods is voluntary in the USA; however, the European Union (EU) has made it obligatory to label products containing GMO. On the other hand, it is not necessary in the EU to label foods with less than 0.9\% GMO (Smyth, Phillips, \& Castle, 2014). EU governments and consumers have a stricter attitude against GM foods on the grounds that GMOs are unnecessary in the production technology. The European Commission conducted Consumer choice and Entrans food projects to examine consumer attitudes regarding GM foods in general as well as risk assessment, risk management, and communication strategies regarding GM food production. In this research, it was found that three in four people stated that GM foods must be labelled clearly because information of GM on the label is misunderstood or misinterpreted. However, there are also some contradictory results. Although half of the respondents stated that they did not buy GM foods, their barcode analyses showed that they bought GM foods (European Commission, 2010). This result shows that GM foods are frequently consumed despite their statement opposing the use of GM foods. In the USA, however, consumers have a more positive perspective about GM foods. Schilling et al. (2002) conducted research in 1203 people and found that, when Americans think about GM foods, they are indifferent about their risks, and respond optimistically. Consequently, the risk perceived by the consumers on genetically modified foods is considerably above the benefit perceived in many European countries, especially Northern European countries as well as United Kingdom and Germany. However, the benefit perception of the consumers on genetically modified foods is higher than the risk perception in USA as well as some European countries like Spain and Italy (Siegrist, 2000). 
In Turkey, the first legislative regulation about GMOs was made on 26 October 2009, and the production of GM plants or animals in Turkey was banned. The same legislation also prohibited the use of GM raw materials in baby foods, baby formulas, infant formulas, and in baby and child food supplements (USDA, 2009). In addition, it is obligatory to label foods containing GMO with the expression that "genetically modified" (Ministry of Agriculture and Rural Affairs, 2010).

There is no consensus about the impact of GM products on human health, especially in the long run (WHO, 2014). According to the World Health Organization (WHO), GMOs contain different genes, and their impact may vary, Furthermore, even though products in the stores have already passed risk evaluations, they may still hold a risk for human health (WHO, 2014). Currently, laboratory studies, experimental field plantings, and production and distribution of genetically modified products are conducted within the framework of regulations formed especially by WHO, and also by national and international organizations and governments.

In addition to studies investigating the advantages of GMOs, there are also many other studies dealing with the economic and political aspects regarding the potential risks (Knox et al., 2011). Genetically modified foods are associated with three health risks including toxicity, allergenicity and genetic hazards (Zhang, Wohlhueter, \& Zhang, 2016). Genetic modified organisms may create a potential toxicity along with changes in the quality of the food. It is stated that they may impair the natural diversity due to gene transfer to untargeted organisms, and that they may also cause possible new virus and toxin formations. Another doubt about GMOs is that they may increase the level of anti-nutrients (Dona \& Arvanitoyannis, 2009).

In the studies conducted on GM foods, it has been found that, in many countries, information, attitudes, and behaviours about this issue vary largely (Yang, Ames, \& Berning, 2015; Ghanian et al., 2016). In one study, it was found that university graduates did not have adequate information about GM foods, and they were concerned about the proliferation of the said products because of their possible risks on human and environmental health and their ethical inconveniences; however, they supported biotechnological practices for medical purposes (Ozgen et al., 2007). In another study, consumers were found to have the idea that GM foods were harmless and they have negative opinions about GM foods (Ghanian et al., 2016). In another study, it was found that a great majority of consumers have negative attitudes about GM foods, they don't want to buy them, and they don't have any knowledge about GM foods (Kahveci \& Özçelik, 2008).

The factors affecting the attitudes of the consumer against genetically modified foods were summarized in Figure 1. 
Şanlier, N., \& Ceyhun Sezgin, A. (2020). Consumers' knowledge level, attitudes, behaviours and acceptance of GM foods. Journal of Human Sciences, 17(4), 1235-1249. doi:10.14687/jhs.v17i4.6016

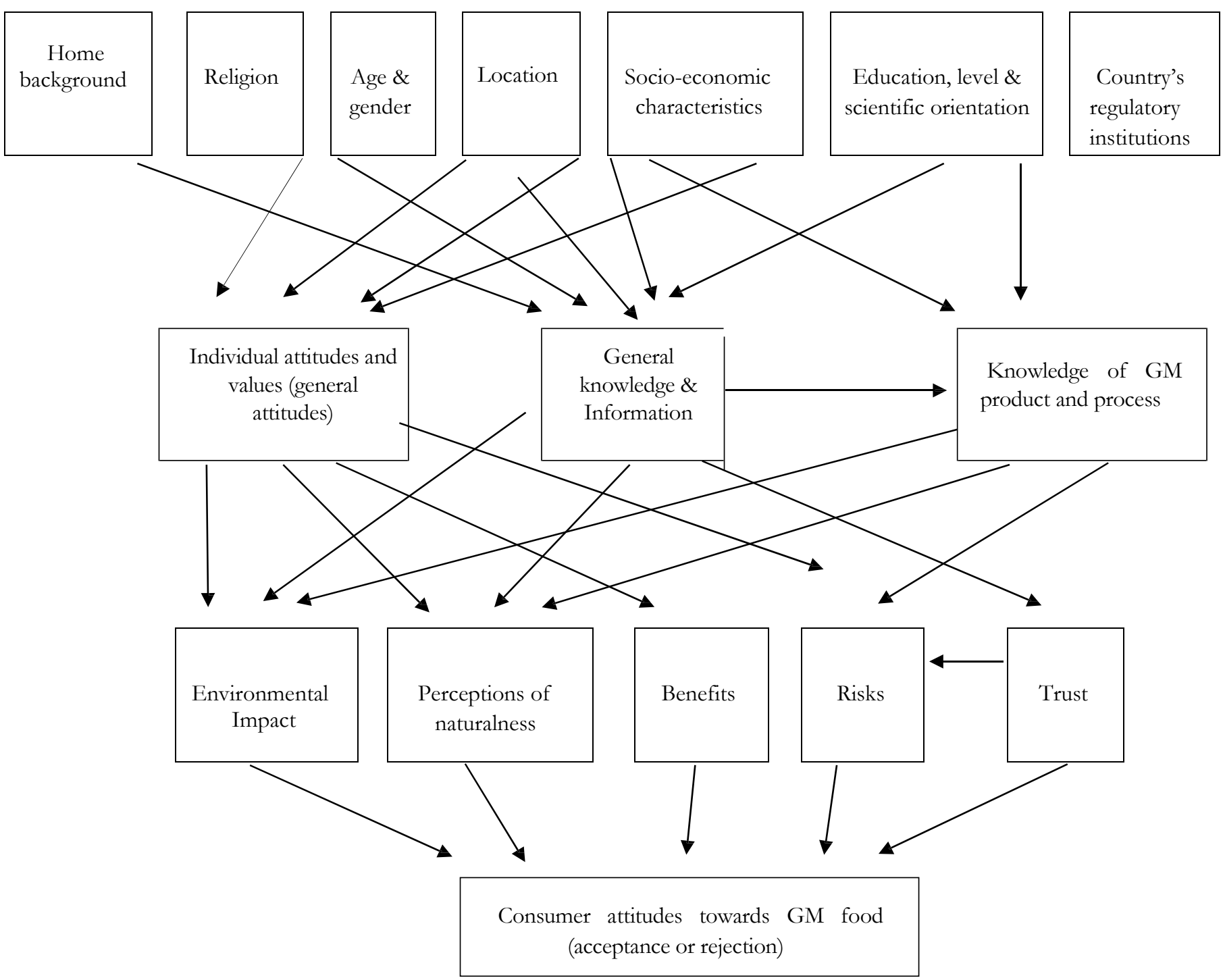

Fig. 1 The determinants of consumers' attitudes to GM food (Hudson, Caplanova, \& Novak, 2015)

Therefore, this study was planned and conducted to examine consumers' knowledge levels, attitudes, behaviours, and perceptions about GM foods and to increase their awareness about the issue.

Based on this back ground, the aim of the present study was to examine the following:

i) whether there is a difference between genders in terms of beliefs about genetically modified foods,

ii) whether there is a difference between knowledge levels in terms of consumers' gender, age, and marital status,

iii) whether there is a difference between the attitudes, behaviours, and perceptions scores depending on consumers' gender, age, and marital status. 


\section{Method}

Investigation

A cross-sectional study was conducted from April to December 2016 on the knowledge, attitude, behaviour, and perception of consumers regarding GM foods in Ankara, Turkey. Participants were informed of the subject and the purpose of the study. Each participant signed a voluntary participation form and filled out the questionnaires, which adhered to the Declaration of Helsinki protocols (World Medical Association, 2008).

\section{Data collection}

This study was planned and executed to determine the GM foods' knowledge, attitude, behaviour and perception of consumers. The research sampling was formed from 706 males, 601 females (totalling 1307) voluntary consumers. Participants in the 17-30 years old. Initially, the aim was to survey 1400 consumers. However, 93 consumers who initially agreed to participate left the study during the survey process. All consumers either graduated or attend a university. The consumers were compared in terms of GM foods knowledge, attitude, behaviour and perception of consumers by gender, age and marital status.

\section{Instrument - Questionnaire}

A questionnaire was prepared by the researchers consisting of 18 questions about consumers' knowledge, attitudes, behaviours, and perceptions about GM foods with the literature review (Fortin \& Renton, 2003; Honkanen \& Verplanken, 2004; Curtis, 2004; Hudson, Caplanova, \& Novak, 2015). A pilot study was employed with 80 people at the beginning of the research. After the pilot study, minor changes were made on the questionnaire.

The data of this research was gathered in three phases:

1. General information regarding age, gender, education and marital status (4 questions).

2. Information questions for participants regarding GM foods (6 "true/false" questions). Answers were graded by giving a point for the right answers and 0 point for the wrong answers given to the questions related with GM foods' knowledge. The GM foods knowledge score is between 0 and 6 . The reliability coefficient of the scale (Cronbach $\alpha$ ) is found as $\alpha=0.87$.

3. Questions regarding the consumers' attitude, behaviour, and perception of genetically modified products (8 questions). Responses to the positive sentences had been graded as follows: "strongly disagree", 1 point; "disagree", 2 points; "neutral", 3 points, "agree", 4 points and "strongly agree" 5 points. Scores regarding GM foods' knowledge vary from 8 to 40 . Croncbach alpha coefficient of internal consistency was used to estimate the reliability of the questionnaire. Alpha coefficient of 0.80 was considered to be acceptable for GM foods' knowledge.

Each questionnaire took $15 \mathrm{~min}$. to administer. Data was collected on weekends and weekdays from consumers.

\section{Statistical analysis}

All statistical analyses were performed using SPSS software. Mean and standard deviation were used for presenting continuous variables (GM foods knowledge and attitude), while frequencies and percentage values were used for categorical variables (gender, age, education level, marital status). Chi-Square $\left(\chi^{2}\right)$ test were used for comparison of categorical variables. For continuous variables, a Student's t-test was used to compare two groups, one-way ANOVA for three or more groups, and Tukey's multiple comparison test. $P$ values of less than 0.05 were considered to be statistically significant. 


\section{Results}

About $46.0 \%$ of all participants were female and $54.0 \%$ were male. It was found that $32.6 \%$ of the participants were 17 to 20 years old, $54.7 \%$ were 21 to 24 years old, and $79.3 \%$ of the participants were married (Table 1).

Table 1 Demographic characteristics of sample

\begin{tabular}{lc}
\hline Demographics & Total $(\mathbf{n}=\mathbf{1 3 0 7})$ \\
\hline Gender & $706(54.0)$ \\
Fale & $601(46.0)$ \\
Age (year) & \\
$17-20$ & $426(32.6)$ \\
$21-24$ & $715(54.7)$ \\
$25-30$ & $166(12.7)$ \\
Educational status & \\
University student & $655(50.1)$ \\
Graduate & $652(49.9)$ \\
Marital status & \\
Married & $1037(79.3)$ \\
Single & $270(20.7)$ \\
\hline
\end{tabular}

Consumers' opinions of GM foods are presented in Table 2.

Table 2 Distribution of consumers opinions about GM foods ( $n=1307$ )

\begin{tabular}{|c|c|c|c|c|}
\hline Expressions & $\begin{array}{l}\text { Male } \\
\text { n (\%) }\end{array}$ & $\begin{array}{l}\text { Female } \\
\text { n (\%) }\end{array}$ & $\chi^{2}$ & $\mathbf{P}$ \\
\hline I heard that the food produced with GMO & $678(54.4)$ & $569(45.6)$ & 1.368 & 0.242 \\
\hline I buy GM foods & $143(56.3)$ & $111(43.7)$ & 0.661 & 0.416 \\
\hline I want a declaration in the GM foods' label & $525(58.9)$ & $367(41.1)$ & 24.491 & $0.000 * *$ \\
\hline I check the label of food if there is GMO content or not & $495(50.7)$ & $482(49.3)$ & 17.499 & $0.000^{* *}$ \\
\hline $\begin{array}{l}\text { GM foods must be labelled correctly and all production } \\
\text { stages should be explained }\end{array}$ & $616(55.0)$ & $503(45.0)$ & 3.338 & $0.040^{*}$ \\
\hline $\begin{array}{l}\text { I want to check the label of food if there is GMO content } \\
\text { but it couldn't }\end{array}$ & $626(52.6)$ & $564(47.4)$ & 10.667 & $0.001 *$ \\
\hline
\end{tabular}

Table 3 Knowledge, attitude, behaviour and perception scores about GM foods according to age and marital status $(\bar{X}, \mathrm{SD})$

\begin{tabular}{ccc}
\hline & Knowledge score & Attitude, behaviour and perception scores $\bar{X} \pm$ \\
& $\bar{X} \pm$ SD & \\
\hline Gender & $4.37 \pm 0.84$ & $26.94 \pm 6.06$ \\
Male & $4.31 \pm 0.81$ & $25.27 \pm 6.57$ \\
Female & $\mathrm{t}=1.031, \mathrm{p}=0.303$ & $\mathrm{t}=4.774, \mathrm{p}=0.000^{* *}$ \\
Age (year) & $4.36 \pm 0.78$ & $28.65 \pm 4.82$ \\
17-20 & $4.32 \pm 0.85$ & $25.89 \pm 6.21$ \\
$21-24^{\mathrm{b}}$ & $4.41 \pm 0.84$ & $21.04 \pm 7.06$ \\
$25-30^{\mathrm{c}}$ & $\mathrm{F}=1.045, \mathrm{p}=0.352$ & $\mathrm{~F}=100.95, \mathrm{p}=1.000$ \\
& $4.29 \pm 0.84$ & Tukey HDS $(\mathrm{a}-\mathrm{b}, \mathrm{a}-\mathrm{c}, \mathrm{b}-\mathrm{c})$ \\
Marital status & $4.53 \pm 0.74$ & $26.55 \pm 5.95$ \\
Single & $\mathrm{t}=4.036, \mathrm{p}=0.000^{* *}$ & $24.74 \pm 7.54$ \\
Married & & $\mathrm{t}=4.189, \mathrm{p}=0.000^{* *}$ \\
\hline ** $<0.001$ & &
\end{tabular}


Although there is no difference between average knowledge scores $(\mathrm{M}=4.37 \pm 0.84$, $\mathrm{F}=4.31 \pm 0.81$ ) on GM foods according to gender, attitude, behaviour, and perception scores are similar (respectively, $\mathrm{M}=26.94 \pm 6.06, \mathrm{~F}=25.27 \pm 6.57$ ). However, the difference is statistically significant $(\mathrm{t}=4.774, \mathrm{p}=0.000)$. While knowledge scores regarding $\mathrm{GM}$ foods according to gender have no statistically significant meaning, the difference by marital status is significant $(\mathrm{t}=4.036$, $\mathrm{p}=0.000$ ). Scores for the attitude, behaviour, and perception about GM foods were found to be statistically significantly different according to age $(17-20$ year $=28.65 \pm 4.82,21-24$ year $=25.89 \pm 6.21,25-30$ year $=21.04 \pm 7.06)$, marital status (married $=24.74 \pm 7.54$, single $=26.55 \pm 5.95)$, (respectively, $\mathrm{F}=100.95, \mathrm{p}=0.000 ; \mathrm{t}=4.189, \mathrm{p}=0.000)($ Table 3$)$.

Consumers' attitudes, behaviour and perception situations toward GM foods is given in Table 4.

Table 4 Consumer attitudes, behaviour and perception situations toward GM foods ( $\%$ )

\begin{tabular}{|c|c|c|c|c|c|c|c|}
\hline Expressions & 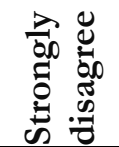 & 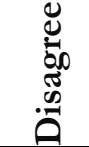 & $\overline{\widetilde{\pi}}$ & 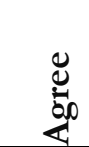 & 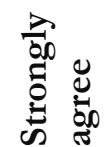 & $\chi^{2}$ & $\mathbf{P}$ \\
\hline $\begin{array}{l}\text { I believe GM foods consumption is good } \\
\text { for health in the future }\end{array}$ & 42.1 & 32.7 & 9.3 & 8.0 & 8.0 & 689.78 & $0.000^{* *}$ \\
\hline $\begin{array}{l}\text { I take serious harmful effects on human } \\
\text { health of GM foods consumption }\end{array}$ & 25.9 & 14.6 & 7.5 & 12.3 & 39.6 & 434.59 & $0.000^{* *}$ \\
\hline $\begin{array}{l}\text { I care about the warnings about harmful } \\
\text { effects on human health of GM foods } \\
\text { consumption }\end{array}$ & 13.8 & 9.6 & 5.6 & 27.5 & 43.5 & 629.67 & $0.000^{* *}$ \\
\hline $\begin{array}{l}\text { I believe that GM foods consumption has } \\
\text { harmful effects on my health }\end{array}$ & 16.0 & 7.2 & 4.2 & 23.5 & 49.1 & 842.79 & $0.000^{* *}$ \\
\hline $\begin{array}{l}\text { I rely on scientists who express that foods } \\
\text { containing GMO have potential risks }\end{array}$ & 10.3 & 12.9 & 10.5 & 32.8 & 33.5 & 380.46 & $0.000^{* *}$ \\
\hline $\begin{array}{l}\text { I rely on people making legal adjustments } \\
\text { considering the potential risks of GMO }\end{array}$ & 10.9 & 12.8 & 12.8 & 34.0 & 29.6 & 310.62 & $0.000^{* *}$ \\
\hline $\begin{array}{l}\text { I rely on European Committee that express } \\
\text { that foods containing GMO have potential } \\
\text { risks }\end{array}$ & 18.4 & 20.3 & 11.9 & 29.2 & 20.3 & 100.80 & $0.000^{* *}$ \\
\hline $\begin{array}{l}\text { I check presence of GM foods in my daily } \\
\text { nutrition }\end{array}$ & 14.3 & 30.3 & 18.7 & 26.3 & 10.3 & 178.74 & $0.000^{* *}$ \\
\hline
\end{tabular}

It was determined that $42.1 \%$ of consumers do not believe that the consumption of GM foods is harmful for health, 39.6\% of them believe that the consumption of GM foods will have harmful effects on human health, and $43.5 \%$ of them care about warnings about GM foods. Furthermore, $49.1 \%$ of the consumers strongly agree with the expression, "I believe that GM food consumption has harmful effects on my health". Consumers were neutral or they disagree with the expressions, "I rely on scientists who express that foods containing GMO have potential risks" $(33.5 \%)$ and "I rely on people making legal adjustments considering the potential risks of GM food" (36.5\%), and $18.7 \%$ were neutral to the statement, "I check presence of GM foods in my daily intake". The differences were found to be statistically significant $(p=0.000)$, (Table 4). 
Şanlier, N., \& Ceyhun Sezgin, A. (2020). Consumers' knowledge level, attitudes, behaviours and acceptance of GM foods. Journal of Human Sciences, 17(4), 1235-1249. doi:10.14687/jhs.v17i4.6016

Table 5 Correlation between consumer knowledge and attitudes, behaviour, perception scores of GM foods ( $\mathrm{r}$ )

\begin{tabular}{lcc}
\hline & Knowledge score & $\begin{array}{c}\text { Attitudes, behaviour, perception } \\
\text { scores }\end{array}$ \\
\hline Age & 0.007 & $0.357^{* *}$ \\
Gender & 0.029 & $0.131^{* *}$ \\
Marital status & $0.118^{* *}$ & $0.115^{* *}$ \\
${ }^{* *} \mathrm{p}<0.001$ &
\end{tabular}

There is a correlation between marital status and GM foods knowledge score $(\mathrm{r}=0.118)$; married participants especially have higher knowledge scores. There is no difference according to age and gender. However, there is a statistically significant difference between age $(r=0.357$, $\mathrm{p}<0.001)$, gender $(\mathrm{r}=0.131)$, marital status $(\mathrm{r}=0.115)$, and attitudes, behaviour, perception scores $(\mathrm{p}<0.001)($ Table5).

\section{Discussion}

As the world has a positive approach to GM foods because of their contributions to the increase in efficiency, decrease in the use of agricultural pesticides, long shelf life, increase in nutritional value, and the prevention of starvation emerging due to increasing population, their impact on human and animal life is disputed (Denli, 2010).

Many studies were conducted on effect of many socio-economic and demographic characteristics including knowledge level on GM foods, educational level, gender, age, ethnic group, residency area and income level etc. on benefit and risk perceptions and attitudes related to genetically modified foods (Curtis, 2004; Gaskell, 2004; Moerbeek \& Casimir, 2005; Ganiere, Chern, \& Hahn, 2006; McFadden \& Lusk, 2015).

In one study, it was found that the majority of Americans did not advocate or oppose GM foods, and that because the potential impact of GM foods is not completely known, they did not believe that there was a need for knowledge and regulations. In response to the question, "Should there be a symbol or information defining GMO on the product?" $92 \%$ of them said "Yes" (Schilling et al., 2002). In this study as well, consumers have expressed similar opinions about GM foods (Table 2). In a study, it was stated that $48.0 \%$ of the participants would consume GM foods if they were persuaded that these foods were safe (Qiu et al., 2012). The results of the study support the results of the present study. However, it must not be forgotten that consumers are still cautious and concerned about GM foods.

Educational level has an impact on the approach to GM foods. Therefore, in order to identify how much the issue of this study is known among highly educated people, university students and graduates were included in the study. Peter \& Karadio (2014) reported that consumers with a higher educational level are more aware about GM foods. Having information about GM foods' affects consumers' choice. In Turkey, studies reported different results about consumers' knowledge level about GM foods. Kaya, Gurbuz, \& Derman (2012) found that university students knew about GMOs and GM foods (\%97.3 and \%75.3 respectively). Ceken (2010) found that participants thought that they had partial knowledge about GMOs or their knowledge level is low about GMO. Similar to the studies in conducted Turkey, studies conducted in the rest of the world report contradicting results. De Steur et al. (2015) stated that Chinese consumers did not have adequate knowledge about GM foods and that they had a sceptical approach to the products. Organisation for Economic Cooperation and Development (OECD, 2000) conference demonstrated that consumers who eat GM foods do not know about what they eat. Consumers want to learn about health benefits and risks about GM foods. International Council for Science (ICSU, 2003) specified that consumers should be informed about allergens and potential harmful effects of GM foods. GM foods meet the needs for public; however, consumer choice is to be respected. 
Şanlıer, N., \& Ceyhun Sezgin, A. (2020). Consumers' knowledge level, attitudes, behaviours and acceptance of GM foods. Journal of Human Sciences, 17(4), 1235-1249. doi:10.14687/ihs.v17i4.6016

Consumer attitudes on GM foods indicate that gender difference is significantly effective and women approach suspicious to such foods when compared with men. Being a parent causes to present sceptical about genetically modified foods and such case does not explain the gender difference on attitudes against GM foods. Furthermore, the confidence on science and information plays an important role to mediate the gender difference (Elder, Greene, \& Lizotte, 2018).

Different views were determined on production and marketing of GMOs among European Union countries. It is detected according to a questionnaire conducted on 16.078 individuals in 15 countries that women have lower possibility to buy GMO foods when compared with men. Furthermore, the label indicating "GMO" was not considered important for those who think to buy these products (O'Fallon, Gursoy, \& Swanger, 2007). It was detected in Germany that $56 \%$ of women and $39 \%$ of men prefer the products with ecological origin. Among the participants, $48 \%$ was found to prefer the products, especially fruits and vegetables which were not modified (Kaynar, 2009). Baker \& Burnham (2001) and Siegrist (2000) detected that women concern about food safety and consider genetically modified foods hazardous than men. Burton et al. (2001) found that there are significant differences in attitudes of the consumers about cisgenesis and transgenesis, and women are against both technologies more than men.

In this study, it has been found that $54.4 \%$ of male consumers and $45.6 \%$ of female consumers have heard about the production of GM foods (Table 2). Men (56.3\%) find GM foods safe more than women (43.7\%) (Table 2). Furthermore, important correlations were found between the marital status and GM foods knowledge scores, and between gender, age, marital status and attitude, behaviour, and perception scores $(\mathrm{p}<0.001)($ Table 3, 5). When the consumers perceive genetically modified products as unnatural products, acceptance level of these products is lower (Frewer, Howard, \& Shepherd, 1996). Costa-Font \& Gil (2009) reported that consumer intent related to genetically modified foods a complex process appeared as a result of an interaction between their attitudes on science, risk and benefit and the confidence to information resources. Those who think that the use of GMOs in agricultural production is dangerous for health, impairs the ecological balance, decreases the biodiversity, and creates a risk for human health display a more negative and sceptical approach. Kocak et al. (2010) found that $62.4 \%$ of medical students did not approve the production of GMOs in Turkey. In another study conducted by Aleksejeva (2014), European consumers were worried whether GMO plants and animals would be harmful to nature or not. When asked for their opinion, consumers expressed this and other similar negative opinions, which are more dominant (Bieberstein et al., 2012). These results support the outcomes of the present study (Table 4). However, results of longitudinal studies and the opinions of producers stating that GM foods are beneficial and healthy are not able to convince consumers, and despite the positive news coming out in the press, there are still concerns about the consumption of genetically modified products (Fortin \& Renton, 2003). Similarly, according to the results of this study, consumers focus more on the harmful aspects of the benefit/harm relationship of GM foods. It is seen that consumers do not have sufficient knowledge about genetically modified foods but that they want to be informed (Tables 2 and 4). The results show a similarity with the outcomes of this study. When consumers' opinions about GM foods are examined in label, it was found that $50.7 \%$ of men and $49.3 \%$ of women buy genetically modified foods (Table 2). In studies about GMO, it was found that the participants perceived GMO as a practice having a harmful effect on health, and they worry about food safety (Uzunkol, 2012; Peter \& Karodia, 2014). In their studies, Bakr \& Ayinde (2014) stated that $56.3 \%$ of consumers are against GM foods. Study results show that consumers, in general, showed a negative attitude about GM foods. The results are in line with the results of this study. Great majority of the participants wanted the GM foods to be labelled and they would not buy a product labelled as a GM food (Demir \& Pala, 2007).

Researched and developments optimizing planting conditions and nutrient content of private agricultural products and GM products (Parisi, Tillie, \& Rodríguez-Cerezo, 2016) would provide commercial advantages for GM products (Kim et al., 2018). However, although information about GMO is obtained from different resources (i.e. media, internet and other news sources), majority of 
Şanlıer, N., \& Ceyhun Sezgin, A. (2020). Consumers' knowledge level, attitudes, behaviours and acceptance of GM foods. Journal of Human Sciences, 17(4), 1235-1249. doi:10.14687/jhs.v17i4.6016

the participants found GM foods as potentially concerning (Wunderlich \& Gatto, 2015). Bawa \& Anilakumar (2013) mentioned that people do not consume the foods of which they do not have information and perceive negative. They detected that these may have negative effects on human or animal health due to lack of information about GMFs which cause negative environmental effects on production processes or agricultural applications. Majority of English consumers think that GMFs are not safe. By decrease of demand to GMFs in many super markets in United Kingdom, such products were removed gradually. European consumers request labelling, transparent and independent safety tests for all GMFs (Pusztai \& Bardocz, 2011). Majority of the consumers in European Union and Japan present a negative attitude against GMFs when compared with American consumers (Tanius \& Seng, 2015). Knowledge level of the consumers living in urban and rural areas of Malaysia/Sarawak Region about genetically modified foods was found very low. The consumers mention that they do not know which products are genetically modified due to lack of information related to genetically modified products on the labels of the product packages (Mahdi \& Zin, 2018). It was detected in Korean Republic that only $5.8 \%$ of the consumers present a positive attitude about GM foods and 58.8\% consider GM foods as hazardous for human health. Another study emphasized that "GMO safety" training is necessary. People with a negative attitude on GM foods or perceiving them hazardous were reported to be those preferring environmentally friendly foods (Kim et al., 2018). Another study detected that GMF is perceived as "unnatural" and "artificial". Positive attitudes against GMFs and desire for buying are associated with personal and social benefits whereas the risk and fear of side effects underlie the negative attitudes. The study results support the outcomes of this research (Table 4). Half of the consumers said that "GM foods must be labelled correctly and all production stages should be explained". However, the food industry argues that labelling should be about the quality of the food, and in particular, half of them object to the labelling of GM foods alleging that consumers would prefer non-GM foods instead of this product when the GM foods are labelled (Phillips \& Hallman, 2013).

Barrena \& Sanchez (2010) determined that factors such as the risk perceptions on food products, health effects of foods, age and income are main variables for the consumers to decide. Importance of socio-economic variables to explain the risk and benefit perceptions against GM foods was also confirmed by Bredahl (2001) and Schlapfer (2008). Grimsrud et al. (2004) concluded that the knowledge level obtained automatically about biotechnology and higher levels of general education increase acceptance of GM foods in Norway. However, Schlapfer (2008) could not find any evidence on association between education and positive attitude against GM products. Despite aforementioned outcomes, there is a consensus that GM foods are reliable and safe for the environment (McFadden, 2016). It has been identified that consumers mostly do not believe that consuming GM foods would be beneficial for health in the future $(74.8 \%)$, and that they seriously believe that consuming GM foods has a harmful impact on human health (65.5\%) (Table 3). In a similar study, participants stated that they were concerned about consuming GM foods (Ozden et al., 2013). The fact that GMOs decrease the usage of pesticides and lead to more quality products affects consumers' opinions (Demont \& Stein, 2013). In their studies, Kaya, Gurbuz, \& Derman (2012) found that $57.0 \%$ of the participants did not think that the negative effects of GM foods would emerge in the short term. However, the effects that these products may have especially on human health in both the short and long run are yet not fully known. Furthermore, if these products threaten genetic diversity, an irreversible process might begin. For all these reasons, it is beneficial to present this type of product to consumers after adequate scientific research has been conducted and to continuously control it within a legal framework. It would be beneficial to inform individuals of all age groups from every sectors of the society through educational activities led by experts to eliminate the knowledge gaps and to increase the society's awareness about safe food consumption. In a study, participants stated that a scientific base was effective in deciding on GM foods (Aleksejeva, 2014). It is thought-provoking that consumers in this study did not trust the scientists who gave explanations regarding this issue $(33.7 \%)$ or people making regulations $(36.5 \%)$ (Table 4$)$. Showing explanations given by experts in the media in order to eliminate these doubts towards GM foods will 
contribute positively to awareness. Many of the studies on attitudes of the consumers about biotechnology and GM foods, in particular (Moon \& Balasubramanian 2001; Lockie et al., 2005) include concerns about nature of technology (Umberger, Thilmany McFadden \& Smith, 2009; Nistor, 2012). Consumer attitudes may change depending on the organism type used in biotechnology field (Bayoglu \& Ozgen, 2010). A study conducted detected that only 37\% of Americans think GM foods safe (Funk \& Rainie 2015). It was stated in one study that consumers request labelling of the products including GM organisms (Brown \& Kuzma, 2013; Jalonick, 2015), and American government enacted a law requiring creation and implementation of a labelling policy standard for GM foods in 2016 as a response to aforesaid concerns (Kerner, 2017). Although GMO herbs are planted in South Africa, it was detected that knowledge of the consumers is limited and there is not any legal enforcement about labelling to affect consumer choice (Botha \& Viljoen, 2009).

In the studies on genetically modified foods, genetic transfer procedures including the plants are accepted more than the procedures including microorganisms and animals (Frewer, Howard, \& Shepherd, 1996; Bayoğlu \& Özgen, 2010; Ribeiro, Barone, \& Behrens, 2016). Grunert et al. (2000) detected that consumers approach negatively against genetic changes on animals than plants. The aforementioned outcomes support our outcomes (Table 2-5). Ceccoli \& Hixon (2012) addressed the importance of scientific information in opinions about attitudes on GM foods. Costa-Font \& Mossialos (2006) determined that religiousness is important to determine the attitudes for cisgenesis. Myskja (2006) observed that religious groups stress non-naturalness of transition species. Furthermore, many religious explanations are reported about GM foods. Huang \& Peng (2015) detected that the rate of the consumers perceiving consumption of GM foods unsafe by more than $30 \%$. They stated that almost half of the consumers do not have information about GM foods and this is caused by the increase of effect of negative media reports about GM foods on GM technology. Furthermore, characteristics such as gender, education and food allergy risk considerably affect their perceptions on GM food safety.

\section{Conclusions}

Although studies conducted on genes have led to exciting results for scientists, bringing them into use after considering their effects on living creatures, health, and the environment during applications (and after sufficient studies are conducted) will eliminate the doubts about genetically modified organisms. Biotechnology's importance in shaping the future is indisputable. However, foreseeing the results that irreversible changes will create, warning relevant people, and raising the society's awareness should be among the primary duties of relevant authorities.

The following suggestions could be made in the light of findings obtained:

People are careful about the health risk of GM foods. For this reason, reliable information should be given to consumers about the composition of the products. Consumers should be educated, taking into account the knowledge, attitude and behavior of people about GM foods. All consumers over the world should have the chance to choose GM foods or not. Considering the consumers' right of choice, labels or warnings should be placed on these products to state that they are genetically modified products. However, labelling does not give knowledge about risks of GM foods. Potential risks must be comprehensible and inclusive. It would be beneficial to train consumers about the risks and benefits of genetically modified products. These products should be placed within the scope of food safety under the control of the government and to conduct risk analyses. Public and private sector should work together. 
Şanlier, N., \& Ceyhun Sezgin, A. (2020). Consumers' knowledge level, attitudes, behaviours and acceptance of GM foods. Journal of Human Sciences, 17(4), 1235-1249. doi:10.14687/jhs.v17i4.6016

\section{References}

Aleksejeva, I. (2014). EU experts' attitude towards use of GMO in food and feed and other industries. Procedia-Social and Behavioral Sciences, 110, 494-501.

Azadi, H., Samiee, A., Mahmoudi, H., Jouzi, Z., Khachak, R. P., De Maeyer, P., \& Witlox, F. (2015). Genetically modified crops and small-scale farmers: main opportunities and challenges. Critical Reviews in Biotechnology, 36(3), 434-446.

Baker, G. A., \& Burnham, T. A. (2001). Consumer response to genetically modified foods. Market segment analysis and implications for producers and policy makers. Journal of Agricultural and Resource Economics, 26, 387-403.

Bakr, S. A., \& Ayinde, O. L. (2014). Consumer attitude towards consumption of genetically modified foods in Arab Countries. Middle-East Journal of Scientific Research, 21(10), 1710-1717.

Barrena, R., \& Sanchez, M. (2010). Differences in consumer abstraction levels as a function of risk perception. Journal of Agricultural Economics, 61, 34-59.

Baylan, M., Mazı, G., \& Gündoğdu, S. (2015). Balık beslemede biyoteknolojik uygulamalar. Türk TarmGrda Bilim ve Teknoloji Dergisi, 3(3), 112-116.

Bayoğlu, S. A., \& Özgen, Ö. (2010). Tüketicilerin tarımsal ve trbbi biyoteknolojiye yönelik tutumları ile fayda ve risk algilarinın incelenmesi. The Journal of International Social Research, 3(10), 91-103.

Bawa, A., \& Anilakumar, K. (2013). Genetically modified foods: safety, risks and public concerns - a review. Journal of Food Science and Technology, 50(6), 1035-1046.

Bieberstein, A., Roosen, J., Marette, S., Blanchemanche, S., \& Vandermoere, F. (2012). Consumer choices for nano-food and nano-packaging in France and Germany. European Review of Agricultural Economics, 40(1), 73-94.

Botha, G. M., \& Viljoen, C. D. (2009). South Africa: a case study for voluntary GM labelling. Food Chemistry, 112, 1060-1064.

Bredahl, L. (2001). Determinants of consumer attitudes and purchase intentions with regard to genetically modified foods-results of a cross national survey. Journal of Consumer Policy, 24(1), 23-61.

Brown, J., \& Kuzma, J. (2013). Hungry for information: public attitudes toward food nanotechnology and labeling. Review of Policy Research, 30, 512-548.

Burton, M., Rigby, D., Young, T., \& James, S. (2001). Consumer attitudes to genetically modified organisms in food in the UK. European Review of Agricultural Economics, 28, 479-498.

Cebirbay, M. A., \& Aktas, N. (2018). Genetiüg değistirilmis organizmalar (GDO) ve etkileri. Gastronomide Güncel Konular, Edition: 1st, Publisher: Billur Yayınevi, pp.309-325.

Ceccoli, S., \& Hixon, W. (2012). Explaining attitudes toward genetically modified foods in the European Union. International Political Science Review, 33, 301-319.

Ceken, R. (2010). Organik tarımın ilköğretim fen ve teknoloji programındaki yeri. Cankır Karatekin Üniversitesi Sosyal Bilimler Enstituisü Dergisi, 1(2), 33-42.

Costa-Font, J., \& Mossialos, E. (2006). The public as a limit to technology transfer. The influence of knowledge and beliefs in attitudes towards biotechnology in the UK. The Journal of Technology Transfer, 31, 629-645.

Costa-Font, M., \& Gil, J. M. (2009). Structural equation modelling of consumer acceptance of genetically modified (GM) food in the Mediterranean Europe: a cross country study. Food Quality and Preference, 20, 399-409.

Curtis, K. M. (2004). Consumer acceptance of genetically modified food products in the developing world. Agbioforum, 7(1-2), 70-95.

Çelik, V., \& Balık, D.T. (2007). Genetiği değiştirilmiş organizmalar. Erciyes Ünv. Fen Bilimleri Enstitüsü Dergisi, 23(1-2), 13-23.

Denli, M. (2010). Genetiği Değistirilmiş Organizmalar. Istanbul Ticaret Odas1, 2010-90.

Demont, M., \& Stein, A. J. (2013). Global Value of GM Rice: A review of expected agronomic and consumer benefits. New Biotechnology, 30(5), 426-436.

Demir, A., \& Pala, A. (2007). Genetiği Değiştirilmiş Organizmalara Toplumun Bakış Açısı. Hayvansal Üretim, 48 (1), 33-43. 
Şanlıer, N., \& Ceyhun Sezgin, A. (2020). Consumers' knowledge level, attitudes, behaviours and acceptance of GM foods. Journal of Human Sciences, 17(4), 1235-1249. doi:10.14687/jhs.v17i4.6016

De Steur, H., Liqun, G., Van Der Straeten, D., Lambert, W., \& Gellynck, X. (2015). The Potential market for gm rice with health benefits in a Chinese high-risk region. Journal of Food Products Marketing, 21(3), 231-243.

Domingo, J. L. (2016). Safety assessment of GM plants: an updated review of the scientific literature. Food and Chemical Toxicology, 95, 12-18.

Dona, A., \& Arvanitoyannis, I. S. (2009). Health risks of genetically modified foods. Critical Reviews in Food Science and Nutrition, 49(2), 164-175.

Elder, L., Greene, S., \& Lizotte, M. K. (2018). The gender gap on public opinion towards genetically modified foods. The Social Science Journal, 55, 500-509.

European Commission. (2010). A decade of EU-funded GMO Research. Project Information, No. EUR 24473 EN.

FAO 2012 (2012). Genetically Modified Crops, Statistical Yearbook Part 4, World Food and Agriculture, Food and Agriculture Organization of the United Nations, Rome.

Fortin, D. R., \& Renton, M. S. (2003). Consumer acceptance of genetically modified foods in New Zealand. British Food Joumal, 105(1/2), 42-58.

Frewer, L. J., Howard, C., \& Shepherd, R. (1996). The influence of realistic product exposure on attitudes towards genetic engineering of food. Food Quality and Preference, 7, 61-67.

Ganiere, P., Chern, W. S., \& Hahn, D. (2006). A continum of consumer attitudes toward genetically modified foods in the United States. Journal of Agricultural and Resource Economics, 31, 129-149.

Gaskell, G. A. (2004). GM foods and the misperception of risk perception. Risk Analysis, 24(1), 185-194.

Ghanian, M., Ghoochani, O. M., Kitterlin, M., Jahangiry, S., Zarafshani, K., Van Passel, S., \& Azadi, H. (2016). Attitudes of agricultural experts toward genetically modified crops: a case study in Southwest Iran. Science and Engineering Ethics, 22(2), 509-524.

Grimsrud, K. M., Mccluskey, J. J., Loureiro, L. M., \& Wahl, I. T. (2004). Consumer attitudes toward genetically modified food in Norway. Journal of Agricultural Economics, 55, 75-90.

Grunert, K. G., Lahteenmaki, L., Nielsen, N. A., Poulsen, J. B., Ueland, O., \& Astrom, A. (2000). Consumer Perception of Food Products Involving Genetic Modification. Results from a Qualitative Study in Four Nordic Countries. Working Paper No 72. MAPP. Centre for Market Surveillance, Research and Strategy for the Food Sector, Arhus, Denmark.

Gurau, C., \& Ranchhod, A. (2016). The futures of genetically-modified foods: global threat or panacea?. Futures, 83, 24-36.

Honkanen, P., \& Verplanken, B. (2004). Understanding attitudes towards genetically modified food: the role of values and attitude strength. Journal of Consumer Policy, 27(4), 401-420.

Huang, J. K., \& Peng, B. W. (2015). Consumers' perceptions on GM food safety in Urban China. Journal of Integrative Agriculture, 14(11), 2391-2400.

Hudson, J., Caplanova, A., \& Novak, M. (2015). Public attitudes to GM Foods. the balancing of risks and gains. Appetite, 92, 303-313.

International Council for Science. (2003). New genetics, food and agriculture: scientific discoveriessocietal dilemmas. ISBN 0-930357-57-4.

ISAAA (International Service for the Acquisition of Agri-Biotech Applications) (2017). GM Approval Database.

Available

at:

https://www.isaaa.org/resources/publications/briefs/53/download/isaaa-brief-53-2017.pdf, (Accessed Date: 08.02.2019).

Jalonick, M. C. (2015). AP-Gfk Poll: An Appetite for Labeling Genetically Modified Foods.

Kaynar, P. (2009). Genetik olarak değiştirilmiş organizmalar (GDO)'a genel bir bakiş. Türk Hijyen ve Deneysel Biyoloji Dergisi, 66(4), 177-185.

Kahveci, D., \& Özçelik, B. (2008). Attitudes of Turkish consumers towards genetically modified foods. International Journal of Natural \& Engineering Sciences, 2(2), 53-57.

Kaya, E., Gurbuz, H., \& Derman, M. (2012). Üniversite öğrencilerinin genetiği değiştirilmiş g1da ürünlerine bakış1. Iğdlr Üniversitesi Fen Bilimleri Enstitüsü Dergisi, 2(3), 55-60.

Kerner, G. S. (February/March 2017). Food for Thought: The Federal GMO Labeling Law. Food Safety Magazine. https://www.foodsafetymagazine.com/magazine-archive1/februarymarch2017/food-for-thought-the-federal-gmo-labeling-law/(Accessed Date: 08.02.2019). 
Şanlıer, N., \& Ceyhun Sezgin, A. (2020). Consumers' knowledge level, attitudes, behaviours and acceptance of GM foods. Journal of Human Sciences, 17(4), 1235-1249. doi:10.14687/jhs.v17i4.6016

Kim, N. H., Hwang, J. Y., Lee, H. G., Song, M. K., Kang, Y. S., \& Rhee, M. S. (2018). Strategic approaches to communicating with food consumers about genetically modified food. Food Control, 92, 523-531.

Knox, O. G., Walker, R. L., Booth, E. J., Hall, C., Crossan, A. N., \& Gupta, V. V. (2011). Capitalizing on deliberate, accidental, and GM-driven environmental change caused by crop modification. Journal of Experimental Botany, 63(2), 543-549.

Kocak, N., Türker, T., Kılıç, S., \& Hasde, M. (2010). Tıp fakültesi öğrencilerinin genetiği değiştirilmiş organizmalar hakkındaki bilgi, tutum ve davranışlarının belirlenmesi. Gülhane T⿰力 Dergisi, 52, 198204.

Lin, C. H., \& Pan, T. M. (2016). Perspectives on genetically modified crops and food detection. Journal of Food and Drug Analysis, 24(1), 1-8.

Lockie, S., Lawrence, G., Lyons, K., \& Grice, J. (2005). Factors underlying support or opposition to biotechnology among Australian food consumers and implications for retailer-led food regulation. Food Policy, 30, 399-418.

Mahdi, A. F., \& Zin, M. Z. M. (2018). Comparing consumer's awareness, attitudes and perceptions towards genetically modified foods (GMFs). Borneo International Journal, eISSN 2636-9826, 1(1), 15-19.

McFadden, B. R. (2016). Examining the gap between science and public opinion about genetically modified food and global warming. PloS one, 11(11), e0166140.

McFadden, B. R., \& Lusk, J. L. (2015). Cognitive biases in the assimilation of scientific information on global warming and genetically modified food. Food Policy, 54, 35-43.

Ministry of Agriculture and Rural Affairs. http://www.resmigazete.gov.tr/eskiler/2010/08/20100813-4.html (accessed 27 April 2016).

Moodie, A. (2016). GMO Food labels are coming to more us groceryshelves-are consumers ready? The Guardian. (24 March 2016).

Moon, W., \& Balasubramanian, S. K. (2001). Public perceptions and willingness-to-pay a premium for non-GM foods in the US and UK. AgBioForum, 4, 221-231.

Moerbeek, H., \& Casimir, G. (2005). Gender differences in consumers' acceptance of genetically modified foods. International Journal of Consumer Studies, 29, 308-318.

Myskja, B. K. (2006). The moral difference between intragenic and transgenic modification of plants. Journal of Agricultural and Environmental Ethics, 19, 225-238.

Nistor, L. (2012). Attitudes toward GM food in Romania. a moral question?. Revista Romania De Bioetica, 10,131-144.

O'Fallon, M. J., Gursoy, D., \& Swanger, N. (2007). To buy or not to buy: impact of labeling on purchasing intentions of genetically modified foods. Hospitality Management, 26, 117-130.

Organisation for Economic Co-Operation and Development (2000). Genetically modified foods, widening the debate on health and safety, The OECD Edinburgh Conference on the Scientific and Health Aspects of Genetically Modified Foods.

Ozdemir, O., \& Duran, M. (2010). Biyoteknolojik uygulamalara ve genetiği değiştirilmiş organizmalara (GDO) ilişkin tüketici davranışları. Akademik Gıda, 8(5), 20-28.

Ozden, M., Akgun, A., Cinici, A., Gulmez, H., \& Demirtas, F. (2013). 8. Sınıf öğrencilerinin genetiği değiştirilmiş organizmalar (GDO) hakkındaki bilgi düzeyleri ve biyoteknolojiye yönelik tutumlarının incelenmesi. Adyyaman Fen Bilimleri Dergisi, 3(2), 94-115.

Ozgen, O., Emiroglu, H., Yıldız, M., Tas, A. S., \& Purutçuoglu, E. (2007). Tüketiciler ve modern biyoteknoloji: genetiği değiştirilmiş ürünlerin kabulüne ve tüketicinin korunmasına model yaklaşımlar. Ankara Üniversitesi Biyoteknoloji Enstitüsü Yayınları, Ankara Üniversitesi Basımevi, Ankara, pp. 254

Paoletti, C., Flamm, E., Yan, W., Meek, S., Renckens, S., Fellous, M., \& Kuiper, H. (2008). GMO risk assessment around the world: some examples. Trends in Food Science \& Technology, 19, 570-578.

Parisi, C., Tillie, P., \& Rodríguez-Cerezo, E. (2016). The global pipeline of GM crops out to 2020. Nature Biotechnology, 34(1), 31-36.

Phillips, D. M., \& Hallman, W. K. (2013). Consumer risk perceptions and marketing strategy: the case of genetically modified food. Psychology \& Marketing, 30(9), 739-748. 
Şanlıer, N., \& Ceyhun Sezgin, A. (2020). Consumers' knowledge level, attitudes, behaviours and acceptance of GM foods. Journal of Human Sciences, 17(4), 1235-1249. doi:10.14687/jhs.v17i4.6016

Pusztai, A., \& Bardocz, S. (2011). Potential Health Effects of Foods Derived from Genetically Modified Plants: What Are the Issues?: Third World Network (TWN).

Ribeiro, T. G., Barone, B., \& Behrens, J. H. (2016). Genetically modified foods and their social representation. Food Research International, 84, 120-127.

Qiu, H., Huang, J., Pray, C., \& Rozelle, S. (2012). Consumers' trust in government and their attitudes towards genetically modified food: empirical evidence from China. Journal of Chinese Economic and Business Studies, 10(1), 67-87.

Peter, L., \& Karodia, A. M. (2014). An investigation into the consumer acceptance of genetically modified foods at the chris hani district municipality, Eastern Cape, South Africa. Kuwait Chapter of Arabian Journal of Business and Management Review, 33(2544), 1-33.

Schilling, B. J., Hallman, W. K., Adelaja, A. O., Marxen, L. J., \& Marxen, L. (2002). Consumer Knowledge of Food Biotechnology A Descriptive Study of US Residents. Food Policy Institute, New Brunswick.

Schlapfer, F. (2008). Determinants of voter support for a five-year ban on the cultivation of genetically modified crops in Switzerland. Journal of Agricultural Economics, 59, 421-435.

Siegrist, M. (2000). The influence of trust and perceptions of risks and benefits on the acceptance of gene technology. Risk. Analysis, 20, 195-203.

Smyth, S. J., Phillips, P. W. B., \& Castle, D. (2014). Handbook on Agriculture, Biotechnology and Development. Edward Elgar Publishing, Canada.

Tanius, E., \& Seng, S. W. (2015). Consumer's awareness towards genetically modified (GM) foods. International Journal of Business, 6(2), 17-26.

Umberger, W. J., Thilmany McFadden, D. D., \& Smith, A. R. (2009). Does altruism play a role in determining U.S. consumer preferences and willingness to pay for natural and regionally produced beef?. Agribusiness, 25, 268-285.

USDA, Foreign Agricultural Service. (2009). "New Turkish Regulation Blocks Imports of Biotech Food and Feed", October 28.

Uzunkol, E. (2012). Sınıf öğretmeni adaylarının genetiği değiştirilmiş organizmalara (GDO) ilişkin algilarının metaforlar aracilı̆̆yla analizi. Eğitim ve Ögretim Arasttrmaları Dergisi, 1(4), 94-101.

Vines, R. (2002). Biotechnology and Plants. Cooperative Extension. Virginia State Univ., Publication No: 443002.

Vujaklija, D. (2006). An introduction to GMO. In 43rd Congress of the European Societies of Toxicology (43; 2006); Congress of Toxicology in Developing Countries (6; 2006).

World Health Organization. (2014). "Frequently asked questions on genetically modified foods", available at http://www.who.int/foodsafety/areas_work/food-technology/faq-geneticallymodified-food/en/ (accessed 3 December, 2015).

World Medical Association Declaration of Helsinki. (2008). Ethical Principles for Medical Research Involving Human Subjects.

Wunderlich, S., \& Gatto, K. A. (2015). Consumer perception of genetically modified organisms and sources of information, advances in nutrition: An International Review Journal, 6(6), 842-851.

Yang, T., Ames, G. C. W., \& Berning, J. (2015). Determinants of consumer attitudes and purchasing behaviors on genetically modified foods in Taiwan. Journal of Food Distributions Research, 46(1), 30-36.

Zhang, C., Wohlhueter, R., \& Zhang, H. (2016). Genetically modified foods: a critical review of their promise and problems. Food Science and Human Wellness, 5(3), 116-123. 